\title{
Designing Cooperative Learning Events for Interpreter Training
}

\author{
Yan Cao \\ Foreign Language School \\ East China University of Political Science and Law \\ Shanghai, China \\ Email: zoe_cao29@163.com
}

\begin{abstract}
Cooperative learning events is a useful supplement to traditional teaching methods in interpreter training. This study seeks to design effective cooperative learning events which could give trainees more opportunities for interpreting practice. Five key elements should be considered when designing cooperation among students. Teachers' instruction and assessment play an important role in promoting cooperation among students. Strategies to increase students' motivation include providing constructive feedback, generating learner autonomy and utilizing positive affect.
\end{abstract}

Keywords-cooperative learning; interpreter training; group work; learner autonomy

\section{INTRODUCTION}

As a communicative act in which the interpreter transfers accurately and quickly what is expressed in one language into another language in order to convey the message, interpretation is a basic linguistic tool that people depend on in cross-cultural communication [1]. The characteristics of interpretation decide that it takes hundreds of hours of practice to achieve interpreting competence. Therefore, interpreter training is supposed to be student-centered and practice-oriented. However, in traditional classroom training, it is difficult to ensure each trainee enough opportunity for practice, due to limited class hours and large number of trainees. The use of cooperative learning events has the potential to supplement traditional pedagogies in addressing this problem by offering enriching possibilities for practice and feedback. It is widely acknowledged that simply putting students in small groups does not ensure success for cooperative learning. In this present study, we are seeking to design effective cooperative learning events for interpreter training.

\section{THEORETICAL BACKGROUND OF COOPERATIVE LEARNING}

\section{A. Definition of Cooperative Learning}

Cooperative learning is a pedagogy within which students are active constructors of knowledge in the learning process instead of passive receivers of any given knowledge [2]. Cooperative learning has been widely recognized as a pedagogical practice that promotes learning among students of different level and across different subject domains. Cooperative learning is when "students work together in small groups to accomplish shared goals" [3]. The students support each other to improve the learning of everyone in the group [4].
Cooperative learning is more student-centered, where the teacher is not the conductor, but the facilitator.

\section{B. Benefits of cooperative learning}

Over 500 studies have been conducted to find out the impact of cooperative learning on students' motivation. It has been found that cooperative learning creates higher self-esteem in the students, higher achievement, and increases students' attitudes toward school and the teacher. Greater collaborative skills, use of higher order thinking skills, intrinsic motivation, more positive psychological adjustment as well as an increased retention of material taught are a few other benefits of cooperative learning [5].

Many scholars have studied cooperative learning versus competition and the traditional way of teaching. The evidence indicates that compared with competitive and individualistic efforts, cooperation promotes more effective communication and exchange of information among students, greater facilitation of each other's achievement, more sharing of resources among the students, greater emotional involvement in and commitment to learning by students, higher achievement motivation by more students, lower fear of failure by more students, greater acceptance and support by peers, more peer pressure toward achievement. It has also been found that cooperative learning experiences result in stronger beliefs that one is liked, supported, and accepted by other students, and that other students care about how much one learns and they want to help one learn [6].

\section{Traditional vs. Constructivist Approaches}

A typical feature of the traditional approach is teacher-centeredness, as the teacher is "the sage on the stage", while the constructivist approach is student-centered, and the teacher is only "guide on the side" [7]. In traditional classroom teaching, students get "a steady diet of drill and practice as they work individually on identical, skill-based assignments to ensure uniformity of learning" [8]. While in the constructivist classroom, students have the opportunity to learn more from working in groups. It puts more of the responsibility on the learner, not the teacher. Dewey [9] felt that students needed to be able to interact with others in order to evolve and grow. This is important because constructivism is based on students being able to interact and learn from each other.

Applefield et al. [10] noted four key elements for constructivist learning: 
1. Learners construct their own learning.

2. The dependence of new learning on students' existing understanding.

3. The critical role of social interaction.

4. The necessity of authentic learning tasks for meaningful learning.

\section{COOPERATIVE LEARNING EVENTS FOR INTERPRETER TRAINING}

In the traditional setting, it is almost impossible to provide each student individual attention because of the limited class hours and large class scale. To move from a traditional approach to the constructivist approach, the teacher must provide well-designed tasks or activities for the group and ensure that the cooperative learning processes are operating. Setting up mock interpreting situations and role-play with study partners provides an opportunity for timely feedback to enhance learning. The following are two major cooperative learning activities designed for interpreter training.

\section{A. Speaking and Retelling Activity}

The purpose of speaking and retelling activity is to improve students' public speaking, analytical listening, short-term memory, note-taking and oral expression. Students work in groups of three. Each member has a different task. The speaker has to prepare a speech on a certain topic in advance. The teacher may give students instructions on the structure, length and content of the speech. The task of another student is to retell what the speaker has just said in source language or target language. After the retelling is finished, a third student is asked to comment on his performance.

\section{B. Speaking and Interpreting Activity}

The speaking and interpreting activity is different from the speaking and retelling activity in that it requires one of the group members to interpret the speech into the target language. The speaker needs to prepare a short speech in advance and gives the speech, while the interpreter needs to interpret the speech into the target language. The reviewer's task is to give feedback to the interpreter's performance, pointing out possible mistakes and highlighting any strength.

\section{Peer Assessment and Reflection}

In both the speaking and retelling activity and the speaking and interpreting activity, group members need to complete a peer-assessment form, which involves the use of rating instruments and checklists to meet the retelling or interpreting task list. For instance, the speaking and retelling activity is rated according to language, content and delivery, while the speaking and interpreting activity is evaluated in terms of accuracy, fluency, articulacy and timing. At the end of the cooperative learning activity, members will pool their wisdom to reflect on their performance and find solutions to the problems in the speaking and interpreting activity. Group members take these roles by rotation.

\section{KEY ELEMENTS IN COOPERATIVE LEARNING}

Simply putting students in small groups does not ensure the effectiveness. When designing the cooperative events, key elements should be taken into consideration. Johnson, Johnson, and Smith [5] describe five necessities to produce excellent results in cooperative learning:

1. The students must have positive interdependence.

2. The students must have positive face-to-face interaction with their group members.

3. The students must be held individually accountable.

4. The students must be using functional social skills.

5. The teacher must ensure that healthy group processes are working.

Putting all of these components into place when designing cooperative learning events is a big job and a serious responsibility on the part of the teacher.

\section{A. Positive Interdependence}

Positive interdependence means that everyone in the group works together to accomplish the goal [3]. Everyone must complete their part of the task, or the group as a whole does not complete the task, and suffers the consequences together. In the cooperative learning activity for interpreter training, each member must complete their part of the task. If the speaker does not prepare well for the speech, the whole activity will be affected. The same holds true for the interpreter and reviewer. All members in a group rise or fall together.

\section{B. Individual Accountability}

Students understand that they have to finish their part of the task, and that everyone must contribute to the group [3]. Individual accountability promotes all students participating in the group, because if someone does not complete his or her part, then the whole group does not complete the task. This is quite similar to positive interdependence. Each member needs to be clear about his task and tries his best to accomplishment his task.

\section{Social Skills}

Interpersonal skills are critical to the success of cooperative learning events. In order to function more effectively, students need to be taught appropriate communication skills such as leadership; trust-building, decision-making, and conflict-management skills [4]. Students learn how they can express their own ideas; acknowledge others' contributions, share materials, and take turns properly so all group members have equal opportunities to participate in the interpreting practice.

\section{Face-to-face Interaction}

Cooperative learning requires face-to-face interaction. The ability to work with group members face-to-face "provides opportunities to develop personal rapport that encourages students to be more willing to reach out to others, listen to what they have to say, and actively work to include others' ideas in the group discussions" [3]. And this goes in line with the nature of interpreting work, in which the interpreter has to face the speaker and the audience.

\section{E. Group Processes}

Group processing involves students reflecting on the learning process [3]. Students analyze how the group functions by identifying group strengths and weaknesses [4]. This encourages students to reflect on their own work and the work 
of other group members to see whether there is any problem in current practice or how they can make progress in future activities.

\section{The Teacher’s Role in Promoting CoOperation AMONG STUDENTS}

\section{A. Redefining Teachers' Role}

According to Richards and Rodgers [11], the teacher acts as the model of language, the lesson planner, the controller of learner practice and the assessor of learner's performance, the organizers in the teaching program in terms of knowledge of grammar, the planners of the course, preparing the materials and deciding what and how learners ought to learn. In the traditional teacher-centered classroom, teachers control the whole process of learning by choosing the material for interpreting training, designing the process of exercises, and assessing the performance of students. While cooperative learning events are student-centered, which means take responsibility for their own learning by choosing materials for interpreting practice, selecting interpreting strategies and evaluating each other's performance.

Although cooperative learning events help shift the learning responsibilities from teachers to students, that does not mean teachers transfer all control to students and thus become a redundant part of the learning process. In fact, teachers still play a vital role. Without teachers' instruction and supervision, cooperative learning events will result in low efficiency or even fall into disorder. Teachers need to motivate students to play to the best of their potentials. And help students plan and carry out their cooperative learning activities.

\section{B. Teachers' Instruction on Cooperative Learning}

These cooperative learning events should first be held in class, while the teacher moves from group to group to monitor and give help if there is any need. Students in one group work together as they struggle to solve problems in the cooperative learning events. Students may use many different strategies to retell or interpret, as there are multiple versions, not just one, in translation. The teacher should also give students detailed instructions as to how to raise relevant questions and give constructive comment so that they could think deeply and reflect on each others' performance.

\section{Teachers' Assessment of Students' Performance}

In cooperative learning, the examination is no longer the only way to assess students. Teachers can use learning journals, notes and portfolios to assess students. In each cooperative learning event, students are required to complete a peer evaluation form and a peer feedback form. Teachers may collect these forms and use them as reference to evaluate students' participation and performance in cooperative learning events. The fact that group members change every several weeks ensure the objectivity of the peer evaluation and feedback.

\section{StRATEgIES TO INCREASE STUdENTS’ MOtIVATION}

Students with higher motivation are more likely to succeed in cooperative learning. The following factors may influence students' motivation, therefore should be taken into consideration while designing cooperative learning events.

\section{A. To Provide Constructive Feedback}

Feedback can improve students' self-efficacy, interest, and intrinsic motivation. So at the end of each cooperative learning event, one of the group members is asked to point out strengths and weaknesses, providing feedback to other members about their public speaking, retelling or interpreting performance. Feedback provides students with motivation to improve on areas of weakness. However, non-constructive feedback such as criticizing can be detrimental, and therefore should be avoided.

\section{B. To Generate Learner Autonomy}

Holec [12] one of the earliest advocates of autonomy in language teaching has defined autonomy as "the ability to take change of one's own learning”. Boud [13] suggests that autonomy is "an approach to educational practice" that emphasizes learner's independence and learner's responsibility. Teachers can support students' autonomy by allowing students to set goals for themselves and providing choices for students to complete instead of forcing them to complete certain activities. Since students will be more interested and motivated to complete work they choose, teachers may ask students to finding materials for retelling or interpreting by themselves, and let them decide roles and attribute tasks among group members. Teachers' encouragement and assist can help students to get rid of uncertainty and anxiety and overcome the obstacles in learning.

\section{To Utilize Positive Affect}

Students will engage in activities that are connected to a positive affect [14]. To increase positive affect, teachers need to provide positive emotions toward interpreting and translation, and demonstrate kindness toward students. Support from other group members is also conducive to positive affect. Thus, teachers should encourage students to develop harmonious and helpful relationships with their partners. Teachers' encouragement and assist can help students to get rid of uncertainty and anxiety and overcome the obstacles in learning.

\section{CONCLUSION}

Cooperative learning is an educational method that boasts increased student engagement and learning. It has the potential to resolve problems in traditional classroom interpreter training. In the cooperative learning activities designed for interpreting training, students carry out autonomous learning in groups of three after class. Each member of the group plays a different role in the group, including a speaker, an interpreter and a reviewer. When designing these activities, five key elements for effective cooperative learning should be taken into consideration. Students should act as the role of center under the guide of autonomous learning theory. They learn and study actively under the teachers' instructions. Teachers shift their roles from a dominator to a facilitator and director. Cooperative learning events should first be held in class so that the teacher may demonstrate how to cooperate with group members and comment on others' performance. In order to increase student motivation, they should be encouraged to give 
constructive feedback to each other. Generating learner autonomy and supporting positive affect are also effective strategies to motivate students to achieve success in cooperative learning events.

\section{REFERENCES}

[1] Mei Deming, “The Advanced Course of Interpretation. Shanghai,” Shanghai: Shanghai Foreign Languages Education Press, 2000.

[2] T. Liang, "Implementing Cooperative Learning in EFL Teaching: Process and Effects,” (Doctoral dissertation, National Taiwan Normal University), 2002. Retrieved from htt:// www.asian-efl-journal.com/Thesis_Liang_Tsailing.pdf (Dec 17, 2016)

[3] R. M. Gillies, "Cooperative learning: Integrating theory and practice," Los Angeles, CA: Sage, 2007.

[4] W. Jolliffe, "Cooperative learning in the classroom: Putting it into practice,” London, England: Chapman, 2007.

[5] D. W. Johnson, R. T. Johnson and K. A. Smith, “Active Learning: Cooperation in the College Classroom," Edina: Interaction Book Company, 1991.

[6] D.W. Johnson, R.T. Johnson and E.J. Holubec, “Circles of learning. (fourth ed.)” Minnesota: Interaction Book Company, 1993.

[7] G. W. Gagnon and M. Collay, "Constructivist learning design: Key questions for teaching to standards," Thousand Oaks, CA: Corwin Press, 2006.

[8] M. Windschitl, "The challenges of sustaining a constructivist classroom culture,” Phi Delta Kappan, 1999, 80(10), 751-755.

[9] J. Dewey, “My pedagogic creed. The School Journal,” 1897, 54(3), pp. 77-80. Retrieved from http://dewey.pragmatism.org/creed.htm

[10] J. Applefield, R. Huber and Moallem, "M. Constructivism in theory and practice: Toward a better understanding,” High School Journal, 2000, 84(2), pp.35.

[11] C. Richards, Jack and S. Theodore Rodgers. "Approaches and methods in language teaching: A description and analysis,” Cambridge: Cambridge University Press. 1986. pp.167.

[12] Herri, Holec, Autonomy in Foreign Language Learning. Oxford: Pergamon, 2001.

[13] D. R. Boud, Cohen, and J. Sampson, (Eds.) Peer Learning in Higher Education: Learning from and with Each Other. London, U.K.: Routledge. 2014.

[14] A. Schweinle, D. K. Meyer and J. T. Turner, "Striking the right balance: Students' motivation and affect in elementary mathematics," The Journal of Educational Research, 2006, 99(5), pp.271-293. 